\title{
Social arrangements. Kinship, descent and affinity in the mortuary architecture of Early Neolithic Britain and Ireland
}

\author{
Chris Fowler \\ School of History, Classics and Archaeology, Newcastle University, UK \\ Email: chris.fowler@newcastle.ac.uk
}

\begin{abstract}
This article reassesses the social significance of Early Neolithic chambered tombs. It critically evaluates inferences about social organization drawn from tomb architecture and interpretations of kinship based on aDNA analyses of human remains from tombs. Adopting the perspective that kinship is a multifaceted and ongoing field of practice, it argues that the arrangement of tomb chambers was related to the negotiation of Early Neolithic kinship. Drawing together inferences about biological relatedness from aDNA analyses with interpretations of chamber arrangements, it suggests that variation in the architectural arrangements and sequential modification of chambered tombs relates to different ways of negotiating aspects of kinship, particularly descent and affinity. It presents interpretations of how kinship was negotiated at Early Neolithic tombs in different regions of Britain and Ireland and concludes that it is increasingly possible to gauge pattern and diversity in Neolithic negotiations of kinship, descent and affinity by combining different strands of evidence, including architectural arrangement.
\end{abstract}

Keywords: Kinship; descent; affinity; chambered tombs; Neolithic Britain and Ireland

\section{Introduction}

The social significance of Early Neolithic mortuary architecture in Britain and Ireland (ca 39003500 B.C.) was given serious consideration in the 1970s and 1980s, but has since played second fiddle to highly productive approaches focused on symbolism, experience and affect. Recent years have seen the suggestion that Early Neolithic communities were 'House societies', and arguments for patrilineal kinship systems based on aDNA analyses. In this article I critically evaluate those interpretations by attending closely to variation in tomb architecture. ${ }^{1}$ After introducing an analytical approach to kinship, I review recent interpretations of kinship and social organization in the Early Neolithic and identify key elements of older approaches which focus on tomb architecture. I propose that chamber arrangements and depositional practices can inform us about Neolithic processes of negotiating kinship over time, processes which varied between and within regions. The second half of the article interprets patterns in the arrangement of chambers at Early Neolithic tombs in different regions of Britain and Ireland as related to different ways of negotiating aspects of kinship, particularly descent and affinity. I argue that tombs - and the human remains they contained - formed a medium and stage for repeated social interaction, not a fossilized record of social relations at any single moment. In some regions, tombs were altered more frequently than in others: the social relations that the construction of such tombs projected towards the future may have been more contingent and potentially unstable in these cases. Some tombs projected forms of kinship and lines of descent forwards in time, while in other cases

( The Author(s), 2022. Published by Cambridge University Press. This is an Open Access article, distributed under the terms of the Creative Commons Attribution licence (https://creativecommons.org/licenses/by/4.0/), which permits unrestricted re-use, distribution, and reproduction in any medium, provided the original work is properly cited. 
chambers seem to have been added in a more incremental way, laying claim to past associations. Alterations to tombs which accentuated their similarity to other tombs might also have been related to changing local and regional networks of affinity. I conclude by identifying some recurring patterns in tomb construction and modification, and presenting some propositions about how kinship was negotiated at specific forms of tombs which can be tested in coming years.

\section{Approaching kinship}

Kinship is a multifaceted field of practice, not an abstract homeostatic structure; kinship is worked on in everyday relationships (Carsten 2004; Johnston 2020, 15-18; Mason 2008), in regular events, and through rarer activities such as mortuary practices. For instance, among the Merina the right to be buried in a tomb with one's ancestors must be earned by tending to that tomb during life, illustrating that one is good kin (Bloch 1971, 119). Kinship can be based on a range of core concepts and metaphors, not just biological reproduction, and understandings of bodily substance including 'blood' vary and can be of varying importance in reckoning kinship (Carsten 2004; Schneider 1984). Kinship is not defined exclusively with regard to other humans, but also to a range of other-than-human beings, though for reasons explained below I will focus on human kinship in this article. People materialize kinship as they act in relation to others - including through the construction and use of buildings. Architecture does not simply 'reflect' social relations, ${ }^{2}$ but forms a medium where kinship and other social relations are articulated during acts of construction, architectural modifications and the repeated use of the space it affects.

\section{Kinship terminology}

The interpretation of Neolithic kinship necessarily draws on anthropological terms and ethnographic comparisons. Here I introduce some key kinship terminology before moving on to ethnographic studies of kinship at chambered tombs.

Lines of descent can be patrilineal, tracing descent down the male line; matrilineal, tracing descent along the female line; or double, tracing both matrilineal and patrilineal descent for each individual. Descent can also be bilateral, where inheritance of different rights may pass to an individual down either line but where there are no corporate descent groups (Stone and King 2019, 150). Patrilineal descent is very common, anthropologically speaking, but can be articulated with different forms of social relations, ideologies of sexuality and reproduction, and gender dynamics (Schneider 1984, 95-8, 169-71). Patriliny should not be assumed to imply valorization of male identities or agency: for example, women are important in the negotiation of relations with neighbouring communities (e.g. through exogamy) (cf. Bickle 2020, 212-13; Brück 2021). Marriage turns non-kin into spouses and affines, ${ }^{3}$ or 'in-laws', and is a vital aspect of kinship which cuts across descent systems. Indeed, maternal parentage and marriage systems play an important role in patrilineal subdivisions: social clustering of brothers from the same mother was noted, for instance, among the patrilineal and polygynous Nuer in the early twentieth century (Stone and King 2019, 71-82). Furthermore, Nuer sons belonged to the patriline of their social father whether or not he was the biological father, women had considerable sexual freedom, and a wide range of kinds of marriage existed, including 'barren' women taking wives and ghost marriages intended to ensure that deceased men could become social fathers (Stone and King 2019, 79-81).

Lineages trace descent from a founding human ancestor, who may be so distant in the past that he or she has a mythic heroic status (Parkin 1997, 17-19): this is sometimes called a segmentary lineage system (e.g. Fleming 1972, quoting Sahlins). ${ }^{4}$ Lineages can also occur within clans, tribes and other social formations. Clan members ultimately all trace descent from an ancestral being of supernatural status: the direct connection between that ancestral being and specific human ancestors is not usually specified (Parkin 1997, 17-19; Stone and King 2019, 64-65). A lineage may be co-residential or may gather for certain events, and for other events may gather with other lineages 
(e.g. those within their clan if they are organized into clans). There are also larger-scale aggregations of kin groups with rather flexible and permeable boundaries, such as tribes (Fried 1975).

While descent forms a key element in kinship, kinship cannot be reduced to descent systems even in societies with strong patrilineal or matrilineal cores (Stone and King 2019, 96). Conventional studies of kinship systems have been critiqued as failing to appreciate the role of substances, things, places and non-human beings in forging kinship and affinity (Johnston 2020, 14-15; Mason 2008), and anthropologists have subsequently explored cognatic kinship ${ }^{5}$ - corporate social institutions that are not exclusively based on direct descent - and highlighted the importance of marriage, affinity and alliance alongside descent (Gillespie 2000a, 1, 8). Age cohorts and sodalities can also cut across kinship systems (Whittle and Bickle 2013, 393-5). Finally, kinship systems may change over time, sometimes rapidly (Ensor, Irish and Keegan $2017,744)$. Although by no means the only arena for cognatic kinship, the study of House societies has emerged from these latter areas of anthropology and has recently been adopted in interpreting Neolithic architecture. ${ }^{6}$

\section{Kinship and house societies}

Julian Thomas has proposed that Early Neolithic communities in Britain were organized into House societies. This follows a boom in the discovery of the footprints of house structures in Britain and particularly Ireland (e.g. Smyth 2014). Thomas (2013, 290-96, inter alia) summarizes his understanding of house societies, drawing on a range of anthropological studies including Lévi-Strauss (1982) (cf. Carsten and Hugh-Jones 1995; Gillespie 2000a, 2000b; Borić 2008; Whittle and Bickle 2013, 389-91; Richards and Jones 2016; ${ }^{7}$ Ray and Thomas 2018; Thomas 2015). 'House societies can combine alliance and descent, matriliny and patriliny, endogamy and exogamy' (Thomas 2013, 291). While the House commemorates founding ancestors, members of the House can trace their descent from the founders via any lineage connection, and in some cases need not even do that: while houses have a core concept of shared ancestry, they may nonetheless be 'preoccupied with the recruitment of outsiders' (ibid., 294). Property (both physical and intangible, such as names and knowledge) belongs to the House rather than to any of its members, and the House is the key moral person in the community. The material embodiment of the House may be a literal house, which may or may not be inhabited by all the members of the House some or all of the time, or it may be some other form of architecture from a canoe to a shrine to a tomb (ibid., 293). While the core of the House is intended to produce a durable medium of continuity, House societies may form and dissipate within short periods, emerging at times of 'rapid change, the transformation of property relations, and the emergence of more bounded and competitive social formations' (ibid., 293). Thomas (ibid., 329, 334) suggests that the short time spans in which houses and halls were built and used in Early Neolithic Britain are intelligible in terms of emergent Houses. He interprets burials at split-post shrines, timber mortuary structures and megalithic chambered tombs as 'house ancestors' (e.g. ibid., 331).

A House is not a kinship system, but House societies organize their kinship systems through Houses; this involves ranking families so that some become core to the foundation of the House and others are more remotely related to that core (and thus are likely to have relatives in other Houses that they could potentially join). Although the extent to which House societies are hierarchical varies (Waterson 1995), Houses vie for position against one another, may include 'nobles' and 'commoners', and in some cases may take and keep slaves - although neither feature is exclusive to House societies. House societies can be cognatic, but it is important to note that patrilineal descent can play an important role within a House even if it is not the only form of descent that members can draw on. ${ }^{8}$ Finally, as Parkin $(1997,23)$ notes, 'it is rarely appropriate to characterise a whole society in terms of any particular mode of descent', and while some members of a community may form a House at a given time, others may not (Gillespie 2000a, 8). 
The flexibility and diversity of House societies present a serious archaeological as well as anthropological challenge. If the category of House societies includes communities with a wide range of kinship systems, power relations and forms of social organization (Waterson 2013, 374), and Houses can be centred on a range of architectural media, then how can we identify a House society and how much can be inferred about social relations once the label has been applied to a Neolithic context? There are compelling archaeological studies of houses as the material media of such long-term institutions (e.g. chapters in Joyce and Gillespie 2000), but Early Neolithic houses in Britain and Ireland do not seem to have particularly long lifespans.

Gonzalez-Ruibal (2006) has noted that houses are important symbolic media in many societies which are not organized into Houses, and produced a summary of nine features derived from Lévi-Strauss's analyses that should be expected in a House society (ibid., 146), including houses as loci of rituals and sacrifices; a 'strong investment in houses (as buildings) and clear differences among houses'; social competition, including monumental houses and prestigious goods, 'titles of nobility, recurrent family names ... [which] can be tracked down through epigraphy, graffiti, coats of arms or symbols depicted in personal belongings or structures'; inherited objects; and a 'significant contribution' to House wealth by women. Many of these categories of evidence are not available for Early Neolithic Britain and Ireland and if this is not simply a matter of preservation then the lack of symbolic media, for instance, may undermine interpretation as a House society. The importance of house architecture as a key symbolic referent is ambiguous. There is a lack of evidence for 'clear differences among houses' and there is little indication of 'heirlooms and elements of rank which are inherited' (ibid.) in the Early Neolithic. We will consider possible interplays between Early Neolithic houses and tombs below.

\section{Kinship in ethnographic studies of chambered tombs}

A recent volume provides a series of informative studies of the use of collective tombs among a range of contemporary communities (Schmidt, Déderix and Crevecoeur 2018). Not every member of society may be buried in the collective tomb but, for those who are, 'Kinship is central to recruitment patterns' (Schmidt and Déderix 2018, 209). Collective tombs appear to be conceived as such from the outset, even if their construction is prompted by the anticipated or actual death of a key sponsor (ibid., 205). It is common to bring the remains of the sponsor's parents or older ancestors into the new tomb (e.g. Couderc 2018; Jeunesse and Denaire 2018, 95), so that it quickly or immediately becomes a collective tomb. While there are cases of patrilineal communities burying their dead in chambered tombs (e.g. Dogon (Mali), Sumba), there are also cases where communal tombs are constructed by communities with cognatic kinship systems. Among the Uut Danum (Borneo) those families sharing a longhouse also share a tomb even though they trace different lineages (Couderc 2018). Bilateral and ambilateral kinship systems, which are attested in House societies, stimulate particularly complex negotiations about where and with whom an individual should be buried. This could result in a greater proportion of individuals who are not close biological relatives within a single monument (e.g. Parker Pearson and Regnier 2018, 52; Schmidt and Déderix 2018, 206-7). In bilateral kinship groups where tomb membership has a patrilineal bias, such as the Merina, tomb members may have lived in different villages from one another: patrilines are really only brought together by tomb membership and form only a part of the tomb community. Merina tombs include those who, in life, may be loose or distant kin, but through tomb membership become part of an idealized descent community (Bloch 1971). Northern Bara communities have patrilineal tombs, yet young children may be buried in the tomb of the mother's patriline (Parker Pearson and Regnier 2018, 52). Even where tombs are described as patrilineal, this may therefore describe only one aspect of a more complex kinship system in which paternal descent is significant but not all-encompassing. The level of diversity within regions in these ethnographic studies is such as to suggest caution about inferring any single 
kinship system for all Neolithic chambered tombs across an area the size of Britain and Ireland and spanning centuries.

The duration of tomb use among House societies may also potentially relate to differing ideas about kinship and ancestry. Jeunesse and Denaire (2018) compare the construction of megalithic tombs among the Lolli (western Sumba) with the use of rock-cut hypogea among the Toraja (Sulawesi). The former are used for around three generations while the latter have been in use for more than ten: Jeunesse and Denaire (ibid.) argue that megalithic tombs indicate a 'brief collectivism' where building a tomb becomes important as something a family should do, contrasting that with the 'long collectivism' of the Toraja tombs, which emphasize continuous presence in a location. Going beyond their text, since Toraja House membership is more fluid than among the patrilineal clans of the Lolli, it may perhaps be that those with greater emphasis on unilineal descent try to demonstrate those kin bonds around once every three generations by constructing a tomb, whereas more fluid and negotiable kinship might draw on a more enduring sense of place and continuity. But other variations are possible and these associations might be locally specific; this could be explored in further ethnographic, historical and archaeological studies.

\section{Inferences about kinship in Early Neolithic Britain and Ireland based on aDNA and stable-isotope analyses of tomb populations}

The analysis of biological relatedness using aDNA has recently been used to interpret kinship. So far the number of Neolithic individuals analysed by these published studies is relatively small under 200 for the entire 1,500-year period across Britain and Ireland at the time of writing although it is growing rapidly. While each aDNA sample provides information about a much wider population than the single individual analysed (Booth 2019, 588), many further individuals still need to be analysed before we have a firm understanding of the degree of variability in biological relatedness among Neolithic communities in Britain and Ireland, and currently very few tombs have aDNA information for more than one or two individuals. Nonetheless, some recent studies have presented interpretations of kinship based on genetic analyses. ${ }^{9}$

Booth (ibid., 595) recently surmised that

in a British context none of the individuals sampled for palaeogenetic analysis from Neolithic tombs and caves are closely related to one another (Olalde et al. 2018; Brace et al. 2019). The variable mitochondrial haplogroups in the same individuals suggests that tombs and caves did not predominantly contain individuals from specific families or lineages.

This may lend support to the idea of broader forms of social unit, such as Houses, or to cognatic kinship systems, or could also suggest that these contexts were not exclusive to kin groupings centred around biological lineages: Ensor $(2021,241)$ warns, for instance, that anthropology suggests that "most kin groups have equated "mothers", "fathers", "brothers", "sisters", "sons" and "daughters" who lack even third-degree genealogical relationships'. However, subsequent studies of Neolithic tombs have inferred biological lineages or close kin. Sánchez-Quinto et al. (2019) inferred patrilineal descent, in part on the basis that more males than females were buried in the four-chambered tombs of varying dates across north-west Ireland and Orkney included in their study (13 male to three female). I am not aware of any anthropological evidence that women are absent from burial grounds in patrilineal societies, however, and the reason for the gender imbalance may lie in factors other than systems of descent. Using shotgun sequencing of aDNA, they also concluded that there were close biological kin relations among three individuals in Primrose Grange Tomb 1 (ibid., 9472), and identified a close biological relation (first or second degree) between an individual from this tomb and one from Listoghil tomb at Carrowmore, roughly two kilometres away (ibid.). In their view, their wider findings do not suggest a 'random 
sample' but indicate the selection of 'patrilineal segments' of society for tomb deposition (ibid., 9473).

Cassidy et al. (2020) suggest the aDNA from a skull at Newgrange indicates a Middle Neolithic elite dynastic lineage practising polygyny and incest, ${ }^{10}$ while their wider data set of samples from passage tombs subjected to shotgun sequencing also suggests 'non-random mating across large territories of the island' (ibid., 386). They concluded of the Early Neolithic portal tomb at Poulnabrone and the Early Neolithic 'atypical' court tomb at Parknabinnia that '[g]ven that there is a lack of close kin within either tomb, we exclude small family groups as their sole proprietors', although ' $[w e]$ interpret our findings as the result of broader social differentiation with an emphasis on patrilineal descent' (ibid.), also citing the predominance of the Y-haplotype I-M284 across Britain and Ireland as evidence for patriliny (ibid.). Dowd et al. $(2020,382)$ report on two Middle Neolithic males from a small tomb at Bengorm in County Mayo, Ireland, who were 'approximately 5th degree relatives' with Y-haplotype I-M284; importantly they accept that since this haplotype was so widespread it cannot be used as an indicator of 'recent male-line kinship' (ibid., 383) at individual sites. Finally, a study of three Early Neolithic individuals from what was probably a wooden chamber at Trumpington Meadows Monument I in Cambridgeshire identified that two of them were brothers (Scheib et al. 2019). This study also commented on the greater diversity of MtDNA haplotypes compared with Y-haplotypes among British Neolithic individuals (ibid., 149), suggesting less genetic diversity among male than female biological ancestors. This may go back to their Continental ancestors.

Bearing in mind that descent is only one aspect of kinship, references to patriliny based on genetic relatedness give priority to a genealogical model of kinship, and, as Johnston (2020, 14) notes, 'the risk is that we take this literally, and the biological relations identified through palaeogenetic analysis become kinship facts'. I do not doubt that these aDNA analyses are detecting genetic patrilines, but in social-anthropological terms the detection of a male biological lineage uniting tomb members could indicate either a strict emphasis on patrilineal kinship or (particularly if a large number of individuals who are not part of that biological lineage are present) a form of cognatic kinship that included a patrilineal element - and in the latter case the community could be organized into Houses. As noted above, patrilineal descent systems can be situated in quite different kinship systems (Stone and King 2019), so their identification is an important first step on the way to interpreting kinship but not the final destination. Furthermore, anthropologists have noted that 'many, though not all, groups with cognatic descent ... have a built-in "patrilineal bias"' (ibid., 155), which makes the difference between some cognatic kinship systems and some agnatic systems very slight. In short, it should not be a surprise if we identify patrilineal descent from aDNA samples in Neolithic tombs, but if we do that is only one starting point for an analysis of kinship.

It is, however, very possible to identify some aspects of kinship systems and burial conventions based on the genetic relatedness of those present in a single burial ground. Returning women's remains to their father's family to be buried in their patrilineal burial ground (e.g. patrilocal tombs) will result in a different composition in that burial ground than if women's remains are retained for burial at her husband's family burial ground (e.g. virilocal tombs), for instance (cf. Ensor, Irish and Keegan 2017, 741).

The fact that certain paternal biological lineages (especially within haplogroup I) were predominant across large areas can make it more difficult to detect whether those from a very close paternal lineage were placed in the same tomb, and the same haplogroups are evident for remains deposited in other contexts, such as caves or enclosures (especially I2a2a). However, detailed comparisons of genome-wide aDNA certainly can detect biological kin distance and form a basis for reconstructing kinship systems. A new study identifies close kin connected by patrilineal descent at the Cotswold-Severn chambered tomb at Hazleton North, Gloucestershire - importantly, this study combines $1240 \mathrm{~K}$ genome-wide aDNA analyses with consideration of the placement of the dead in six distinct compartments which form two separate chambered areas. This integration of 
the genetic and contextual archaeological evidence allows the authors to identify that the locations within the tomb of 27 out of 35 sampled individuals are consistent with a virilocal patrilineal descent system in which maternal descent clusters were also significant (Fowler et al. 2021). One male in the first generation reproduced with four women, and some of the descendants of two of these women were consistently placed in the south side of the tomb over several generations, suggesting that descent from a specific maternal ancestor was significant in deciding where to place the dead. The patterns are strong enough to also detect the inclusion of males whose mother reproduced with a lineage male but who themselves had a different biological father: these males may have been adopted as sons by lineage males, suggesting adoptive kinship was practiced (ibid.). There are also eight individuals who are not biologically related to the patriline, which might suggest wider adoption, other social criteria for kinship, or the inclusion of nonkin within the tomb. We can therefore infer a patriline in social-anthropological terms, while also noting that maternal sub-lineages were important and that tomb membership was negotiated as well as by right of birth.

Stable-isotope analyses have been used to detect variations in diet and in-life mobility. These are not by themselves indicators of kinship but can support inferences about shared and differing practices among those buried together. For example, stable-isotope analyses by Samantha Neil and colleagues suggest the relocation of groups of people founding tombs in central to western Britain in the 38th century, finding comparable results at Whitwell, Derbyshire (Neil et al. 2020) and Penywyrlod, Brecon (Neil et al. 2017). The sampled individuals had non-local signatures, and one from the north-east Chamber II at Penywyrlod (dated to 3770-3630 cal. B.C.) potentially had a similar distant origin to those at Whitwell. The authors suggest that these individuals grew up in northern France, although parts of south-west England and Scotland have geologies that could produce such results (Neil et al. 2020, 521). Evidence for similar Neolithic artefacts and mortuary structures can be found in Scotland around this time, but the authors favour a direct relocation from France to a chain of mobility. Wherever those individuals spent their childhood, ${ }^{11}$ the analyses demonstrate long-distance mobility of a group of people who were later buried together, probably after founding the tomb as they settled. So far, results from the 37 th century do not indicate such long-distance relocation (ibid., 523). Those on individuals from both sets of chambers at Hazleton North are similar enough to infer a group who moved around the landscape together, repeatedly spending some time locally and some time on a different geology at least 40 kilometres distant: the tomb might have been visited within annual patterns of residential movement or more intermittently for several generations during this century (Neil et al. 2016). While we cannot directly reconstruct kinship practices from stable-isotope results alone, co-residence can be a key basis of kinship and the results suggest that the tomb was used over a few generations by a community with a consistent curriculum vitae, including those now known to form a related descent group (Fowler et al., 2021).

Taken together, these recent studies infer varied degrees of biological relatedness among those within each tomb, from unrelated individuals at Parknabinnia to the two brothers at Trumpington Meadows to a patriline at Hazleton North. This suggests diversity in kinship systems or in how kinship related to tomb use. The architecture of these sites is also varied. The Poulnabrone portal dolmen, where no close biological kin have been identified, is single-celled, and the long chamber at Parknabinnia is subdivided into two compartments (Jones 2019), while Hazleton comprises six cells in two separate chambered areas. We should not expect that tombs from different regions and centuries would include the same combinations of biological kin and biologically unrelated individuals, and much further study is needed to detect pattern and diversity. Ideally, such studies would combine aDNA and stable-isotope analyses with appreciation of the kind of location where the dead were placed and how they were placed in relation to one another (cf. Ensor 2021). We also need to produce hypotheses about the archaeological evidence, and interpret kinship from a social perspective in which biological genealogy is one part of a wider social picture. The placement of the dead and the forms and sequential modifications of the tombs are crucial here. 


\section{Building kinship at Early Neolithic tombs: arranging descent and affinity Building on previous approaches}

Some important explorations of the social aspects of Neolithic mortuary architecture have been overlooked for some time. Andrew Fleming (1972) explored what he called 'the segmentation principle' in tomb morphology. Where a single mound housed several chambers he argued that this was 'a fossilised record of the fission and fusion principle' which Sahlins (1961) identified as fundamental to segmentary societies. For Fleming, Neolithic builders flexibly assembled multiple chambers and compartments to suit their local and changing social relations; he refers to LéviStrauss's concept of bricolage (Fleming 1972, 72). Julian Thomas (1988) argued that the separation of bone and flesh within tombs in southern Britain suggested a community distinguishing between kin and affines (ibid., 553). He argued that tombs with multiple chambers separated the dead by sex and particularly age categories, while tombs with a single chamber, which he considered to be later, indicated increased social cohesion. Thomas has also argued that human remains were manipulated to produce 'persons from whom descent could be claimed' (Thomas 1999, 151), and concluded that tombs were the province of 'bounded and inclusive social entities (such as "tribes" and "clans")' (ibid., 226). Whittle (2003, 131; cf. Whittle et al. 2007a, 134) considered the possibility of open and closed descent groups building such monuments, asking - but not yet answering - important questions about the significance of bilateral chamber arrangements at Cotswold-Severn tombs. ${ }^{12}$

Recent approaches to mortuary practices and Early Neolithic monuments have more often focused on cosmology, personhood, experience and affect. The transformative nature of the process of monument construction has been explored, and the contingent, emergent aspects of that process have been highlighted (e.g. McFadyen 2006). Early Neolithic tombs have also been interpreted as places of transformation where the living transformed the dead into ancestors, and the implications of processes of bodily transformation at tombs have been explored in interpreting personhood and embodiment during the period (e.g. Cummings, Jones and Watson 2002; Fowler 2001; 2002; Fowler and Cummings 2003; Thomas 2000; 2002). The symbolic and experientiael affordances of the arrangement of stones at tombs suggest that tomb construction involved some careful decisions about the selection and positioning of stones and other materials (e.g. Jones 1999; Cummings 2002). The role of relations with animals, plants, places, rocks, soils and trees has been considered in the Early Neolithic in general (e.g. Banfield 2018; Fowler 2003; Noble 2017; Pollard 2006), and these are likely to have been important media in both monument assembly and the negotiation of kinship. Cummings and Richards (2021) suggest that portal dolmens, an early type of megalithic monument, were places where people related to other-thanhuman beings in a spiritually charged world whether or not human remains were lodged there (cf. Whittle 2003, 132). It has been suggested that relations between intermarrying human communities and their respective herds of cattle might have operated in equivalent ways (Ray and Thomas 2003), and that the bodies of the human dead were inserted into non-human 'bodies' that were teased apart to allow access when they were transformed in making monuments (e.g. oak trees, cattle, large rocks; cf. Fowler 2021a; 2021b). While the role of non-human beings in kinship remains a crucial and fertile area for discussion, and may have been particularly prevalent at some points in the Neolithic, in what follows I will focus on the further potential of the spatial arrangements of chambers that contained human remains, and their uses in mortuary activity, for exploring kinship. However, it should be clear that ultimately these different areas of analysis should all be combined, and that kinship is a key field of practice in which personhood, gender, ontology and cosmology are all articulated (Carsten 2004; Creese 2012, 370; Fowler 2016, 399-400; Johnston 2020, 15-18).

Andrew Powell (2005) made an important contribution to understanding kinship through the chamber arrangements of Irish chambered tombs, although so far it has not been widely cited. Powell argued that tomb design 'reflects elements of a social and ritual discourse ... that 
promoted an ideological and idealized view of a particular set of social relationships' (ibid., 12). He considered that tombs drew together a community but different types of tombs set up different conditions for tracing kinship. A chain of chambers at a court tomb 'portray their community as a single entity stretching back from the living to the dead' (ibid., 12), but some court tombs in Ireland have a central court with two separate chains of chambers, which he proposed 'symbolize the splitting of the lineage into two segments (or moieties), each looking out into the landscape in opposite directions' (ibid., 15). He also noted the high degree of adaptation of the general design, so that 'within some 370 court tombs, few have structurally identical designs' (ibid., 13). By contrast, single-chambered portal dolmens presented a single undifferentiated community of the dead 'for which extended lineage relations were not put forward as a defining characteristic' (ibid., 20); instead, these presented 'a visible display of strength and solidarity'. The general idea that the arrangement of chambers related to the negotiation of kinship is a key part of the argument pursued below, though I diverge from Powell's interpretation in places. This emphasis on site plans and chamber arrangements should not be viewed as dismissing or ignoring the importance of work on the emergent properties of monument construction, contingencies of practice or experiential aspects of tomb architecture. I am simply focusing on one feature of tomb architecture in this article.

The remainder of the article builds on the observations above to explore the further potential of the architecture of chambered tombs to contribute to understanding kinship in Early Neolithic Britain and Ireland. The emphasis will lie on the different strategies these communities developed in negotiating kinship, affinity and descent through architecture, particularly the arrangement of chambers within tombs. I will argue that variations and modifications in Early Neolithic tomb architecture were bound up with different ways of negotiating kinship, descent and affinity, but while I have adopted a loosely regional structure it should be stressed that strategies which were dominant in some regions were present to some extent in other regions too: there are few hard and fast regional boundaries as the distribution of specific chamber arrangements and tomb exteriors was discontinuous, uneven and overlapping. Analysis of Neolithic kinship needs to operate at a range of scales, from detailed contextual analysis of single tombs to pairs and clusters of local tombs to regional and transregional comparisons, and what follows aims to sketch out one framework for this.

\section{Lineage, duality and extension in central to western southern Britain}

Early Neolithic tombs were built from wood or stone, or a combination of both. Pairs of wooden posts made from oak tree trunks split longitudinally are among the earliest Neolithic constructions. These can be interpreted as megaxylic shrines (e.g. Fowler 2010, 18; Thomas 2013, 325, 327), and were often subsequently chosen as places to deposit human remains. In some cases, these posts were incorporated into the chambers of wooden structures, and in some of those cases medial posts were placed between the two end posts, dividing the shrine space or mortuary area in two. At Fussell's Lodge, Wiltshire, one post was removed before some of the human remains were deposited, probably during an extension in which the length of the chamber was doubled (Noble 2006, 75-78; Wysocki et al. 2007) (figure 1). Fussell's Lodge included remains from individuals who died more than one generation before others at the site and before the chamber was constructed (ibid.). Such remains may have consisted of bones of preceding kin previously lodged at a different locale or stored in the expectation that a tomb would one day be built. The modelled sequence of dated remains indicates that older remains were placed at the rear of the chamber and more recent ones at the front, in a broadly linear sequence connecting the dead across several generations in a single, extended chamber. Contemporary domestic architecture in central to eastern England also exhibits such extension, forming a conjoined pair of houses (e.g. Lismore Fields, White Horse Stone) (Barclay and Harris 2016), which could be interpreted as derived from a new kin partnership and/or cohabitation with a second generation. This does not mean that such 


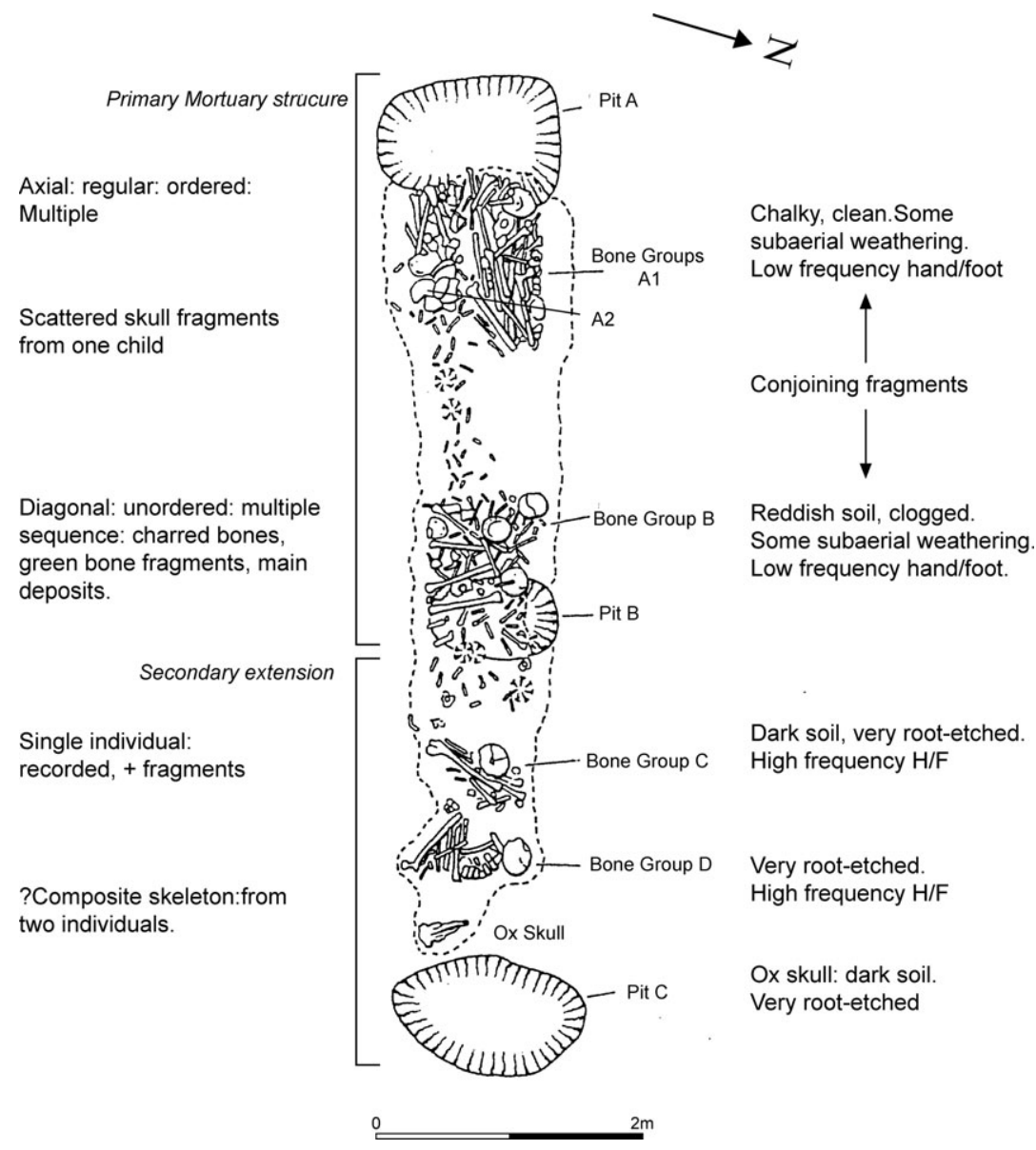

Figure 1. Split tree-trunk posts and mortuary chamber at Fussell's Lodge, Wiltshire. Source: Wysocki, Bayliss and Whittle (2007). By kind permission of Alasdair Whittle.

houses and tombs were built by people with the same kinship systems, nor that tombs and houses stood in the same relation to kinship, and these structures are not local to one another. However, we may be able to identify common processes in the articulation of kinship in these cases by attending to the 'sharing of architectural cues' (Leary, Field and Barclay 2020, 10).

Pairs of opposed chambers occur at a number of Cotswold-Severn tombs. The chambers here are more clearly separated by cairn material or a passage space than the subdivisions at wooden mortuary chambers, suggesting a greater social separation between the dead buried on either side of the division. The tomb at Hazleton North includes two tripartite chambered areas with layouts that mirror each other across the central linear axis of the mound. Ancient-DNA analysis suggests that a single patriline connects at least 27 of those buried in the tomb, and that which first-generation woman an individual was descended from was a significant factor in deciding whether to bury an individual in the north or south side of the tomb (Fowler et al., 2021). Duality is evident in the construction of the mound, the chamber arrangement and the selection of the dead. This suggests an interest in two lines of descent subdividing a patrilineal community from the time the tomb was constructed. This pattern was disrupted on one side when the northern passage collapsed, blocking access to the north chamber for some members of the second and third generation. The alignment of descent grouping with chamber arrangement strongly suggests that 


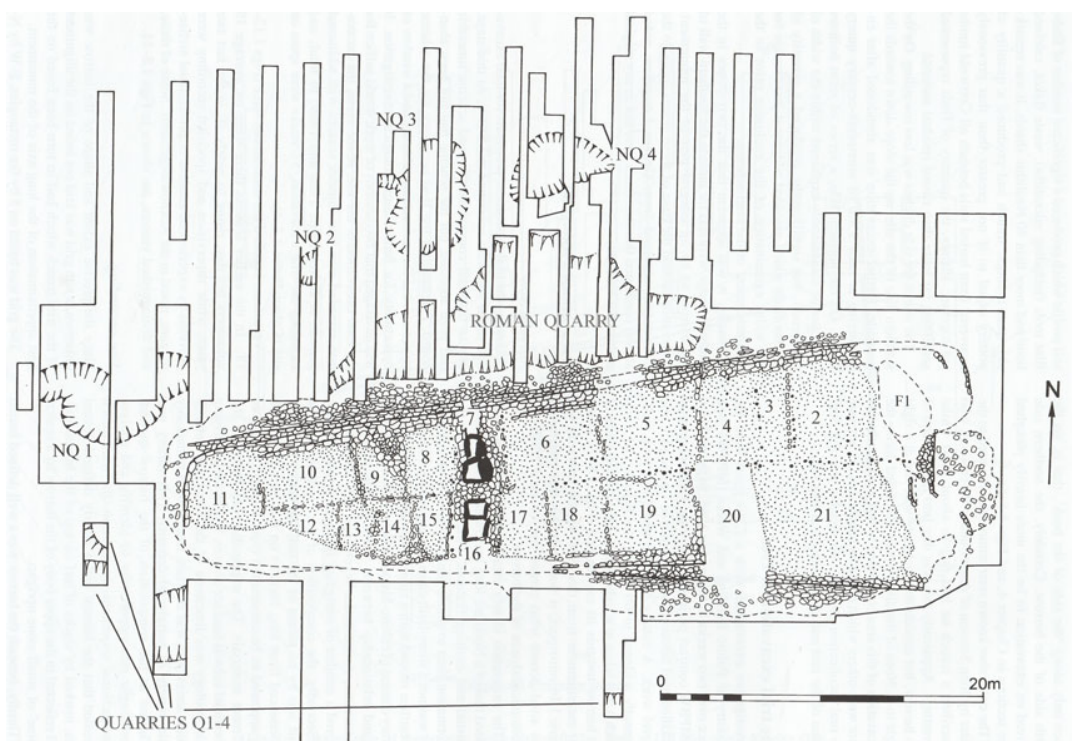

Figure 2. Plan of the long cairn at Ascott-under-Wychwood, Oxfordshire. Source: Benson (2006). By kind permission of Alasdair Whittle.

chamber layout related to kinship, reinforcing the view that chamber arrangements were social in nature. Even though the architecture was not deliberately modified, depositional practices changed over time when the collapse of the northern passage diverted the flow of practice. A second, similar, as-yet unexcavated tomb lies only $80 \mathrm{~m}$ away.

Ascott-under-Wychwood is another thoroughly investigated laterally chambered CotswoldSevern tomb. The chambers form a pair of two compartments, constructed contemporaneously in the late 38th or the 37th century B.C. (figure 2). The cists were constructed as part of a single 'transverse corridor' later blocked in (Whittle et al. 2007b, 329), with only a one-metre space between the two sets of chambers. Whittle et al. (ibid., 335, 359) suggest that the placement of the chambers may cite a pre-existing duality in the placement of wooden structures either side of the formation of a midden decades before the chambers were built. There are also indications of further organic partitions within some of the chambers (McFadyen, Benson and Whittle 2007, $86,90)$. Two of the individuals from the northern inner chamber and three from the southern outer chamber shared a congenital spinal pathology that suggests they may be related (Galer $2006,205,210)$. The northern outer chamber was empty and while this may suggest that the planned use of chambers was sequential (Whittle et al. 2007b, 359), it is also possible that this chamber was not used for other reasons. The most recent burials at the tomb were in the southern middle chamber (Bayliss et al. 2007, 42), not the outer chamber, suggesting that linear temporal sequence was not mapped out in a spatial line.

Therefore, projecting descent categories may have been an important concern in the very conception and design of these two sites, neither of which was reconfigured using its use life (unlike some of the tombs discussed below). It does not appear that the dead were intended to be placed in a single linear sequence of descent, one generation to each compartment. Rather, the tombs presented a community united in one place yet divided into two, and at Hazleton North individual compartments were used in successive generations most often by those sharing the same sub-lineage. Sub-lineage divisions may also have been projected for the future at Ascott-underWychwood, whether or not those were used. Ancient-DNA analysis would help assess this possibility. 
Pairs of chambers occur either side of a single central passage at West Kennet (Wiltshire), Wayland's Smithy II (Oxfordshire), Nympsfield, Notgrove and Burn Ground (all Gloucestershire), among other sites. At Burn Ground, Smith and Brickley identified seven conjoining bone elements between two of the chambers on the south side of the passage (Smith and Brickley 2009, 65-66), suggesting connections between those deposited on this side of the monument. West Kennet was used for such a short time during the Early Neolithic that it is not possible to ascertain any sequence in the use of chambers (Bayliss, Whittle and Wysocki 2007, Table 1): chamber membership might well have related to kinship distinctions, though aDNA analysis would be needed to detect biological relatedness. The use of a shared passage at these terminally chambered tombs means the different cells can be accessed from the same central place, while at laterally chambered tombs the access to chambers on one side was secluded from view to the other side. As Thomas $(1988,553)$ noted, the former arrangement indicates a closer relation between all those using the tomb than the latter. Since most of the terminally chambered tombs have later dates than most of the laterally chambered ones it is possible that the unity of the community was increasingly accentuated at newly constructed tombs after ca 3600 BC. Perhaps Cotswold-Severn tombs with terminal 'false doors' and accessible side chambers, such as Belas Knap, implied a past line of connection between the side chambers, now intangible, in the way that lineages within clans share a common ancestor without tracing a complete continuous line of descent. Thus these tombs might operate partly to distinguish two lineages or sub-lineages and partly to denote their shared distant or mythic origin.

Bayesian-modelled date ranges for the use of Waylands' Smithy I, Waylands' Smithy II and West Kennet are perhaps compatible with the model of brief collectivism over three generations proposed for Lolli tombs by Jeunesse and Denaire (2018). However, most tombs in the region seem to have been used for around five generations or so, which fall between 'brief and 'long' collectivism. The extent of continuity may assist with understanding how tombs relate to descent systems, with those exhibiting a briefer collectivism placing greater emphasis on continuous genealogically focused descent practices. Some of the episodes of deposition at both tombs with long and short use spans included the remains of those who died violent deaths, as evidenced by arrowheads among the remains at Wayland's Smithy I (Whittle, Bayliss and Wysocki 2007, 107) and an adult buried at Ascott-under-Wychwood (Galer 2006, 199). In some cases, tomb construction or modification may have been prompted by such traumatic events, but in either case they could have had a dramatic impact on a line of descent and wider kin.

\section{Projecting and altering lines of descent in western Britain and Ireland}

Lines of chambers are evident in many regions, sometimes set in pairs and sometimes extended over time. Some court tombs in Ireland have a central court dividing two groups of chambers, as at Ballyglass, where a conjoined pair of chambers stand either side of the court (figure 3). As Smyth (2020) explains, one of these is close to the remains of a defunct house but not quite aligned with it. The chamber arrangement could present two social units, each itself potentially subdivided in some way, coming together in a unified plan on the site of a house which may have been ancestral to one or both groups. The presence of such paired chambers or sets of chambers has previously led some to suggest a social division into two moieties (Powell 2005, 15). Fleming $(1972,63)$ followed De Valera $(1960,35,43)$ in suggesting that court tombs in the north of Ireland derived from a form of moiety organization because of an insistence on two and four segments, and the relative rarity of three'. This is a tempting interpretation, although caution is needed, particularly if extending the idea to neighbouring regions.

The majority of linear chamber arrangements in Britain and the Isle of Man occur as single rows, including at tombs with external courts. Tombs with linear chamber arrangements sometimes exhibit a chain of three chambers (e.g. Ballymacdermot, County Armagh; Clady Halliday, County Tyrone; Crarae and Auchoish, both in Argyll; Dunan Beag, Sliddery Water, Sannox, and 


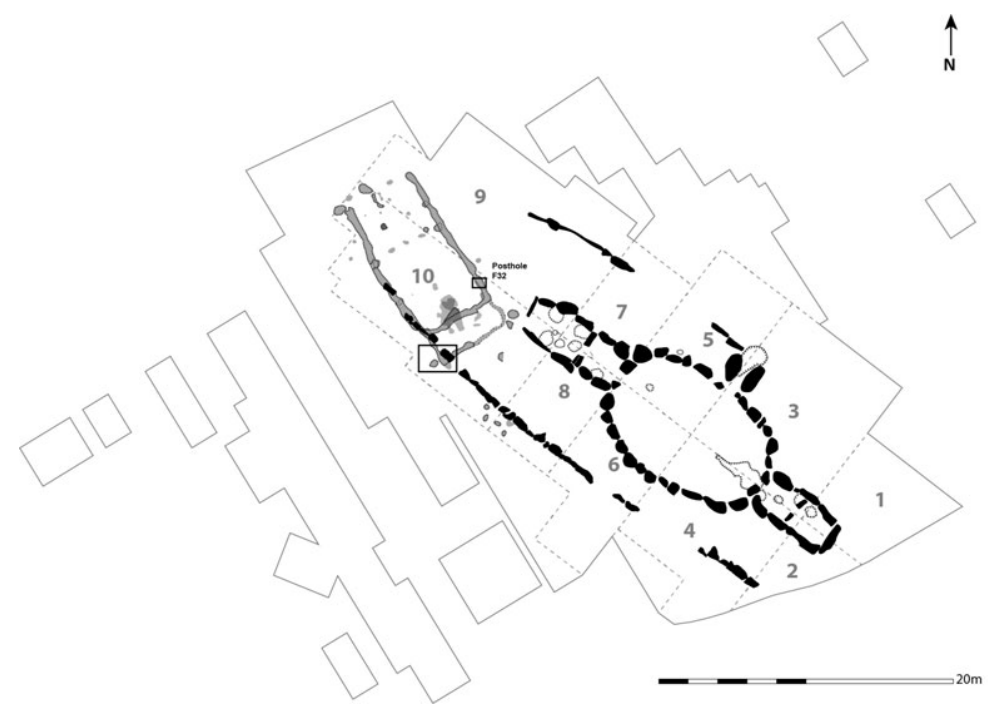

Figure 3. Early Neolithic house and court tomb at Ballyglass, County Mayo. Source: Smyth (2020). By kind permission of Jessica Smyth.

two of the three sets of chambers at Dunan Mor, all on Arran; and Bicker's Houses, Bute, King Orry's Grave Southwest, Isle of Man) and sometimes a row of five (e.g. East Bennan, Arran; Clettraval, Uist; Cashtal yn Ard, Isle of Man (figure 4a)). If built in a single phase, a row of two to five chambers might set up conditions not only to trace ancestry but to project descent into the future: i.e. in anticipation and hope of future continuity. Yet some of these rows of chambers may have been extended rather than built at one time. In their final form at least the frontmost cell was accessible from the entrance and at King Orry's Grave Southwest the rear chamber could be reached or reached into via a portal (cf. Fowler 2004); at Cashtal yn Ard the rear chambers may have been sealed off or only accessible with effort from above. The incidence of cremated remains at linear-chamber sites is also higher than among the paired chambers of southern Britain. This may suggest emphasis on a more rapid transformation of the dead prior to deposition, or, in some cases, multi-stage interactions in which some remains were processed further and then redeposited (cf. Cooney 2016). The chamber arrangements at each site may therefore relate to different traditions of engagement with the remains of the dead as well as strategies in the projection of different spans of time or categories of kin, person or ancestor.

Jones $(2019,993)$ lists several cases where it seems that pairs or sections of chambers at court tombs in Ireland were constructed successively rather than at the same time. There are also examples of Early Neolithic houses in Ireland which are conjoined or nearly conjoined linear pairs, as at Plaster, Louth (Smyth 2014, 27, 32), and some are divided into two rooms. Smyth (ibid., 60) refers to a 'linear and generational' sense of time, evidenced by the timing of acts of deposition and house construction and destruction. It could be suggested that generational sequence, pairing and extension or growth over time were key tropes in kinship across houses and court tombs in this period, although not all of these houses are from regions where court tombs were constructed and some were near clusters of portal dolmens (see below). By contrast, extension is not seen in the roughly contemporary timber halls in lowland eastern Scotland, a region with very few chambered tombs. Perhaps kinship was reckoned differently here or the construction of houses pre-empted future kin development, or only took place once certain kin relations were achieved.

Some linear arrangements of chambers illustrate changes in the direction of contiguous chambers or passages, as at Pipton, Powys (figure 4 b), where four compartments are contiguous while a 


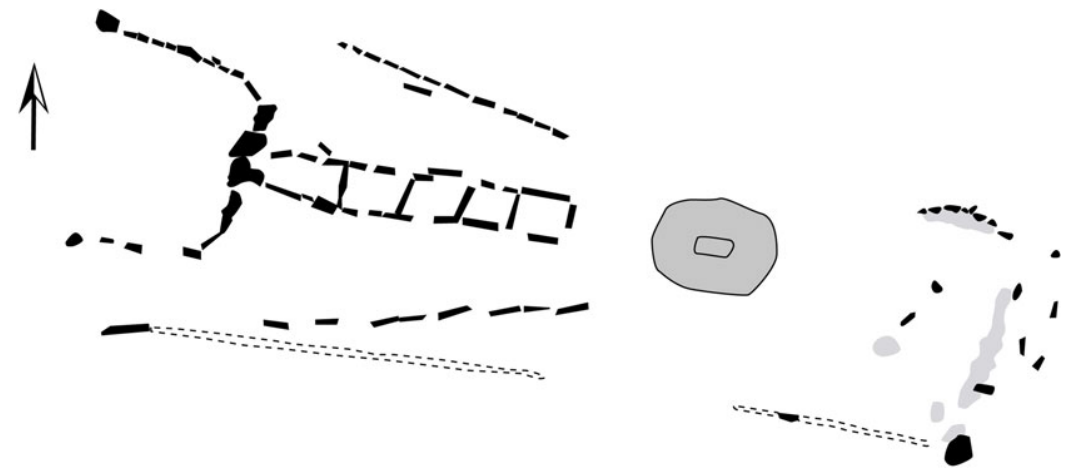

Figure 4a. Court cairn at Cashtal yn Ard, Isle of Man. Redrawn by Mareike Ahlers (after Lynch and Davey 2017).

Figure 4b. Long cairn at Pipton, Powys. Redrawn by Mareike Ahlers (after Corcoran 1969).

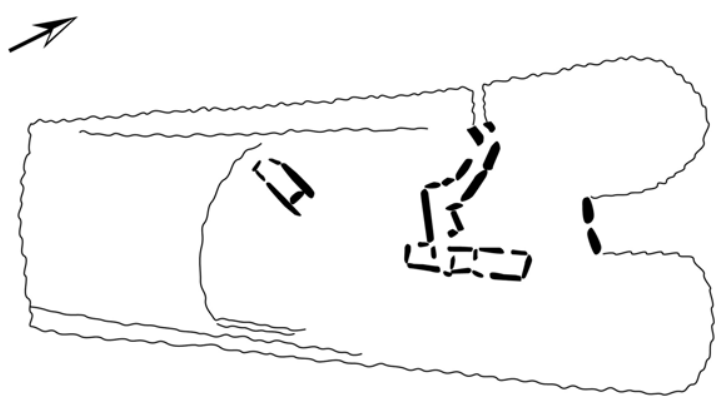

further chamber was isolated within the cairn along with its human remains, some of which were stacked in a structured fashion (Wysocki and Whittle 2000, 599). The connections and separations among the dead were seemingly rearticulated several times, with the orientation of the longest chain of chambers expressing several changes of direction. This sequence could present a historical narrative, contingently tracing changing relations, rather than a projection of a single line of kin forwards in time. It stands between the projection of lines of relatives into the future and the adaptation of simple structures into more complex arrangements.

\section{Single-celled chambered tombs, tomb extension and changing affinities in Ireland and western Britain}

As at Pipton, many Early Neolithic chambers were constructed as single cells, at least initially. Some may not have been built as tombs: dolmens in western regions, for instance, could have been more like shrines (Cummings and Richards 2021), perhaps equivalent to the timber split-post structures which saw subsequent deposition of human remains in eastern and northern regions (Fowler 2021a; 2021b). While some small wooden chambers in the south and east of Britain were not extended and received only a few bodies (as at Trumpington, Haddenham, or Nutbane), some single-celled stone structures in the west attracted a large number of remains and remained unmodified, suggesting differences in the significance or nature of kinship. Other stone chambers were joined by additional chambers and incorporated into new or extended cairns which clearly had a mortuary function. One or more generations of the same community could have built a single-celled tomb in one place, then a second in another, then returned to add further chambers at the first. 


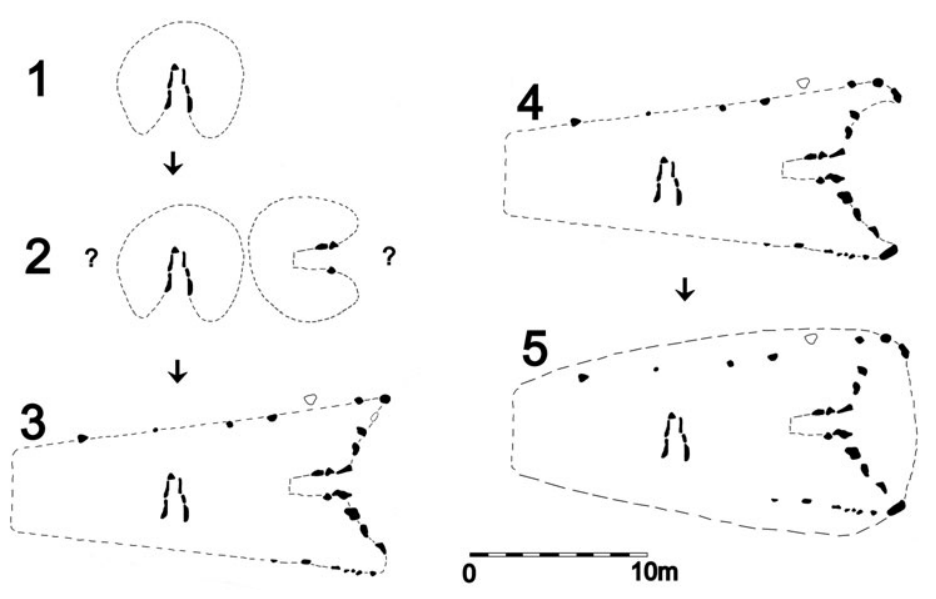

Figure 5. Long cairn at Blasthill, Argyll. Source: Cummings and Robinson (2015). By kind permission of Vicki Cummings.

Powell (2005) argued that single-celled tombs emphasized the unity of the kin group, but this need not mean that those contained within were part of a single lineage. One of the only singledcelled tombs with aDNA results available from multiple individuals, Poulnabrone, does not include close biological kin (Cassidy et al. 2020). Some such structures may not have been associated with the production of close human kinship, or might have been built and used by cognatic kin groups. Nonetheless, duality may be built into such monuments in other ways: as Cummings (2002, 251-52) illustrates, for instance, the orthostats on one side of the portal dolmen at Carreg Samson are made of rough stone while those on the opposite side are smooth. These likely derive from two different parts of the landscape. She notes something similar at Cairnholy II where the juxtaposition of stone textures matches differences in the landscape either side of the tomb (ibid., 253). The significance of this pairing might not be the same as sites with paired chambers - it might have more to do with the transformation of a body from a rough, decaying form to smooth bones than to kinship (cf. Cummings, Jones and Watson 2002), or conjoining two zones of the landscape - but such juxtapositions could be polyvalent, particularly if different bodily substances were considered to derive from maternal and paternal ancestry. Cummings (2002) also highlights the different curvature of the left and right side of the facade at Cairnholy I and pairing of stones with different textures. The kinds of relations negotiated at locations such as Cairnholy early in their history may have been quite different to a focus on linear human descent, though further aDNA analyses at single-celled tombs are needed to test this idea, but their later history may have seen increasing concern with descent.

Single-celled chambers were also frequently joined by a second chamber, and sometimes more, but these chambers were not 'paired' in the same way as suggested for Cotswold-Severn laterally chambered long cairns. At Blasthill, Argyll, a circular cairn and its linear single-cell chamber were later incorporated into a long cairn with a forecourt and terminal single-celled chamber set at 90 degrees to the orientation of the first chamber (Cummings and Robinson 2015) (figure 5). This second chamber may also have preceded the long cairn within its own circular cairn. The sequence may suggest changes in the composition of the community in which two units, potentially associated with different places or directions, became integrated over time. The forecourt facade to the second phase was also later modified to produce a more curved profile, commensurate with court tombs in Ireland and on the Isle of Man (ibid., 24). This may indicate a sense of affinity with those communities; indeed, one possible explanation for a change in tomb and chamber orientation is a shift in the kin groups intermarrying.

Tombs themselves often occur in pairs or small clusters. The interplay between tombs in clusters, and between similar forms of tombs in neighbouring clusters, could potentially also relate to the generation of kinship and affinity. For instance, a series of free-standing circular cairns were 


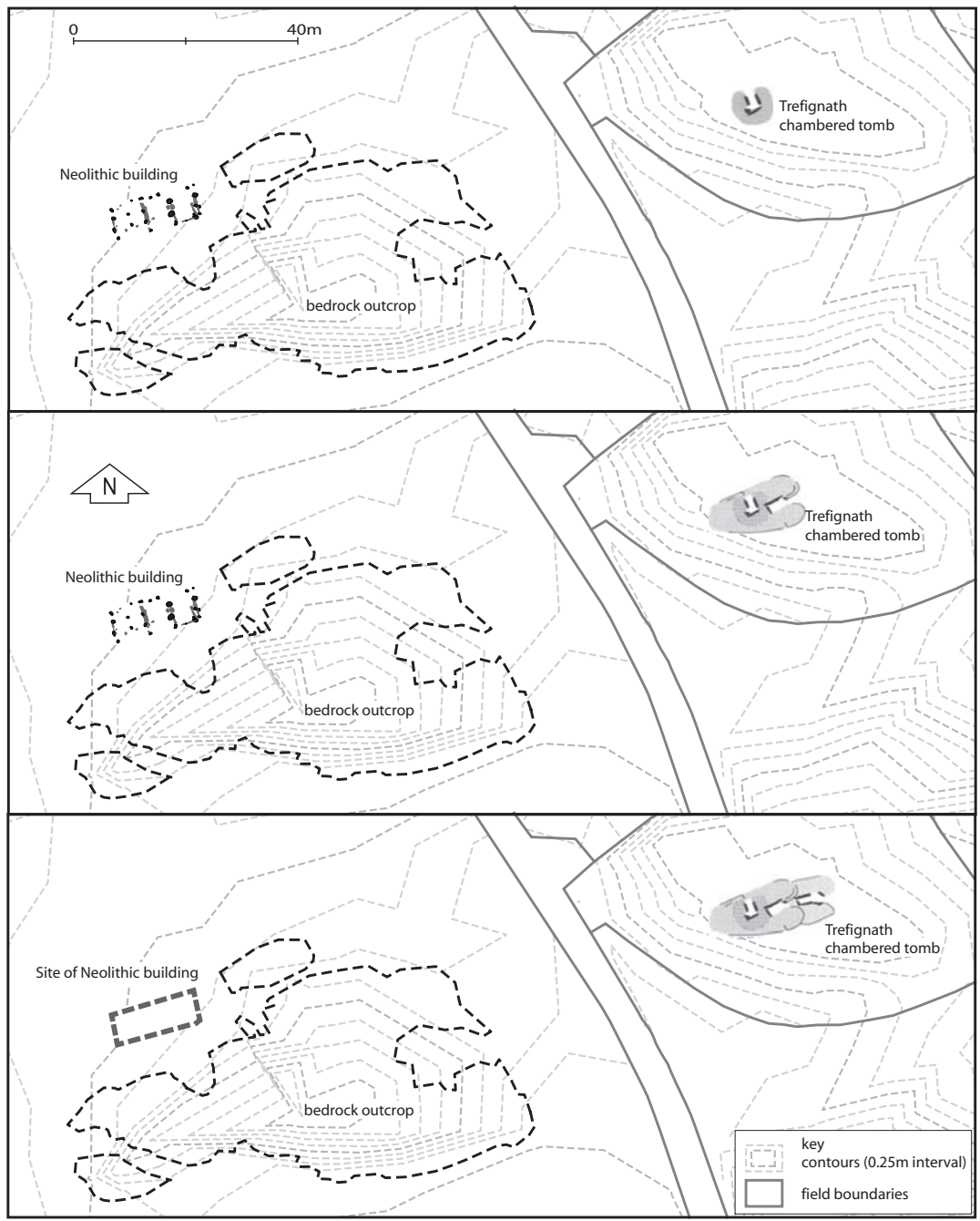

Figure 6. Early Neolithic house and sequence of tomb construction at Trefignath, Anglesey. Source: Kenney (2020). By kind permission of Jane Kenney.

built at Mid Gleniron in Galloway and eventually transformed into two linear cairns. Initially, two single chambers 120 metres apart shared the same north-west-south-east axis, but subsequent single-chambered round cairns were built up against these with a north-east-south-west axis, and finally two long cairns engulfed these chambers and their circular cairns. There is an interesting interplay here not only between the chambers within each tomb but also between the two emerging tombs. This may signal new subdivisions to the community and/or that affines from new groups or areas were joining the community, and perhaps a more pronounced role for duality over time. One of the tombs again eventually sported a curved, almost horned, facade.

Such architectural interplay can arguably also be seen between houses and local tombs, as at Parc Cybi and Trefignath, Anglesey, where Jane Kenney $(2020,140)$ describes a 'dialogue between the two'. Here a linear three-celled house was aligned east-north-east on a single-celled tomb 100 metres away with a northerly entrance; the second chamber constructed at Trefignath adopted that east-north-east orientation (figure 6) (ibid.). The final chamber and eventual long cairn 
continue this axis. The house aligned on a tomb, which was realigned on the house and continued that historical relationship into the future even after the house was disused.

Ethnographic studies of megalithic tombs offer little insight into the practice of extending sites or adding chambers to existing tombs - they rather seem to indicate that building a new tomb periodically was an important concern for societies emphasizing unilinear descent. By contrast, in Early Neolithic Britain and Ireland, adapting and elaborating an existing tomb was a common strategy. This has been interpreted as a change in cultural affiliation or tradition, a 'melding of distinct traditions and identities' (Sheridan and Schulting 2020, 203), but it could also be seen as resulting from shifting kinship practices and networks of affines, and changing ontologies. Perhaps it was particularly important in these cases to stress the longevity of a burial site and the community's (claimed) connection to the dead from preceding generations without removing those remains to a new site. This was often done in a way that produced the possibility for increasing spatial subdivisions among the dead and a shift from a round mound to a linear mound: this linear form was already present early on in most regions (both for houses and for tombs), but its popularity as a monumental form spread over time in Britain. This might perhaps relate to a growing emphasis on each community tracing linear descent (though this need not be unilinear descent) and/or acknowledging a sense of affinity between tomb-building communities near and far. The linear extension of Early Neolithic mounds and addition of chambers from the 37th to the 35th century B.C. can be contrasted with the proliferation of clusters of passage tombs with round exteriors during the 35th and following centuries in parts of Ireland and Orkney in particular.

\section{Conclusion}

While identifying patterns and differences in the layout and modification of tombs does not give us a final resolution on the kinship systems practised, it illustrates how Neolithic kinship can be appreciated as an active process in which the remains of the dead and the structure of a tomb formed ongoing media for the repeated renegotiation of kin relations. While we should not expect that kinship 'explains' all factors in tomb construction and use, trends and diversities in these practices may be key to understanding how vital aspects of kinship were negotiated and renegotiated over time. Early Neolithic kinship practices can be understood as part of a dynamic process spanning generations. They anticipated the future as well as looking to the past. Until recently the generational scale has been obscured by imprecise chronological resolution, but Bayesian modelling has begun to change that, while aDNA analysis increasingly affords the possibility to detect biological relatedness within and between tombs at the generational scale. Indeed, it is conceivable that in coming years we could have substantial detail about who was biologically related to whom from a number of Neolithic sites. It is therefore important to keep considering the role that mortuary architecture and mortuary practice played in the negotiation of Neolithic kinship. In so doing, we need studies of aDNA and stable isotopes which include detailed information on sample location within sites, consider inferences about social relations with reference to a wide range of kinship practices, and acknowledge that kinship ideals - such as those projected in tomb design may not always be followed rigidly in practice and may change within a few generations.

The interpretation of kinship in Early Neolithic Britain is a challenging topic, even with the emergence of extremely promising new scientific techniques. Archaeological interpretations of Neolithic evidence, scientific analyses (particularly aDNA) and anthropological studies each rest on partial evidence: variable preservation, varied quality of excavation and recording, varied survival of material for sampling and so on. Different studies also grapple with different aspects of kinship, from biological relatedness to interactions with cattle to the shaping of social space. None of these alone gives a rounded picture of kinship yet combining them is not straightforward. Even in a cognatic kinship system, tomb membership may exhibit a patrilineal bias so the identification of patrilineal descent in a tomb population may not be enough by itself to refute the possibility of a 
broader cognatic kinship system. Bilateral descent combined with virilocal burial may produce a mortuary population with a strong patrilineal genetic signature. The identification of house structures is not enough per se to identify a House society with the attending social ranking that LéviStrauss identified. Neolithic tombs that cite the architecture of houses (which by no means all do) may suggest that the house was a core social institution, but there are ethnographic examples of patrilineal societies constructing tombs and houses. Projecting and tracing descent - however that is reckoned - are a widespread concern, and varied ways of negotiating descent through tomb construction and modification have formed a key element in the interpretations put forward in the latter part of this article.

This article has therefore emphasized the practice of kinship in tomb construction and modification, as well as depositional practice, in tracing and projecting descent and affinity. As a starting point, these monuments were diverse and could be adapted in different ways. Kinship, descent and affinity could all be remodelled. Relations between the human dead could be given greater or lesser emphasis; the dead could be treated collectively in a way that transcended lineal biological descent; or lines of descent could be framed singly, dually, in a straight line, at angles and with changes of direction; they could be extended, end or shift elsewhere. At times, these social arrangements organized or reorganized the remains of those who had died recently or some time ago, and at other times they projected a desired or idealized sense of community continuity into the future. Those who built tombs which held their initial form while being used over several generations, such as Hazleton North and Ascott-under-Wychwood, might be seen as particularly successful in generating descendants who followed their ways; the modification of tombs in other regions might suggest more overt dynamism in the negotiation of kinship and affinity. The interplays between chambers, between tombs and between pairs and other patterns are complex and varied, and unravelling these requires working beyond the level of a single site or a single type of monument or a single region.

I hope this article will stimulate further debate on the articulation of kinship, affinity and descent in the Neolithic, and I acknowledge that there are other aspects to kinship it has not had space to explore. Kinship is inseparable from personhood, age, gender, social organization, cosmology and ontology, and the motivations for the different spatial layout of Neolithic tombs and the ways they were used are likely to have derived from understandings of kinship in relation to such other factors. Equally, Neolithic architecture cannot be understood in isolation from landscape, substances, artefacts, other contemporary architecture and the bodies of humans, animals and trees. Recent interpretations of Neolithic tombs in Britain and Ireland have, however, seen greater focus on such topics than on kinship, and it is hoped that future research will more fully integrate all these aspects.

Acknowledgements. I would like to thank Vicki Cummings, Lisa-Marie Shillito, Alasdair Whittle, and two anonymous reviewers for invaluable comments on earlier drafts of this article; Marieke Ahlers for producing the drawings in figure 4; and Vicki Cummings, Jane Kenney, Jessica Smyth and Alasdair Whittle for permissions to reproduce copyrighted images.

\section{Notes}

1 It is important to question the appropriateness of referring to these monuments as tombs and debate exactly which megalithic monuments can be considered tombs. There is a substantial overlap (literally) between tombs and unchambered cairns and mounds, and not all megalithic arrangements were used primarily to deposit the dead (cf. Cummings and Richards 2021). The use of the term 'tomb' in this article is not meant to imply that all megalithic structures were places to leave the dead, nor that the dead were laid in these chambers to rest in peace, nor that they were only places of burial. Lodging the remains of the dead at the same place repeatedly no doubt had many varied effects and meanings, transforming place as much as person. But I do consider that the structures discussed below at some point in their history and for some part of their significance acted as places where the dead were assembled together. At that point, I would suggest that those using them were often concerned about human kinship, among other things.

2 The term 'architecture' is here used to refer to the assembly of a monument and its assembled form together, since these are best understood as works in progress throughout their use spans. I am primarily concerned in this article with the architectural 
arrangement of tomb chambers but also consider mound forms and extensions; however, there are many other aspects to the architecture of these sites which should not be overlooked (see below).

3 While 'affines' refers to those who have become kin by marriage, in a broader sense it can also refer to a feeling of similarity or connection and refer to those of cognate status.

4 While Powell describes a 'lineage' split into two moieties, a moiety is generally considered as comprising two intermarrying lineages both of which may trace unilineal descent.

5 Cognatic descent can also include lineal descent where each individual can draw on both maternal and paternal connections to past ancestors. As Stone and King $(2019,143)$ point out, 'there is sometimes only a fine line between forms of descent that are called by different names'.

6 The term 'House' has been capitalized where referring to a social institution rather than a physical structure.

7 This article considers only the Early Neolithic. Later Neolithic Orkney demonstrates clearer interplay between house and tomb architecture such as the merging together of more than one house 'cell' at passage tombs (e.g. two at Quanterness and Quoyness, four or five at Holm of Papa Westray South) as well as at houses in the settlements at Barnhouse and Ness of Brodgar (Richards 2005; Richards and Jones 2016; cf. Fowler 2021b). Such variation in houses (and tombs) seems a stronger fit to Gonzalez-Ruibal's criteria of house differentiation.

8 Levi-Strauss's first examples of House societies were patrilineal, though he included cognatic communities in subsequent work (Gillespie 2000b, 27-28).

9 Osteological analyses have sometimes detected similar non-metric traits or pathologies among individuals within a tomb. Some of these suggest a close degree of genetic relatedness, although it is not possible to say exactly how close (Smith and Brickley 2009, 92-4).

10 This seems a significant interpretive leap from one sample, but there is not space for a proper critical assessment here. 11 While there is no intention here to doubt the interpretation of a Neolithic brought to Britain from northern regions of France by people from those areas, nor that the tomb building, mortuary practices and artefacts at these sites are similar to those from northern France, there are wooden mortuary structures in Scotland that pre-date or are contemporary with Whitwell, so it remains possible that those buried at Whitwell grew up in Scotland (even if some or all of their parents or grandparents had lived on the Continent).

12 Whittle (2003) also provides an important dissection of the impact of anthropological studies of ancestor veneration on the interpretation of Neolithic mortuary practices, and stresses that kinship systems are ideological whereas lived practice can be varied in relation to that ideology.

\section{References}

Banfield, E., 2018: Animals and ontology. Addressing the role and meaning of faunal remains in the Neolithic long barrows of Wessex, unpublished $\mathrm{PhD}$ thesis, Leicester University.

Barclay, A.J., and Harris, O.J.T., 2016: Community building. Houses and people in Neolithic Britain, in P. Bickle, V. Cummings, D. Hofmann and J. Pollard (eds), The Neolithic of Europe, Oxford, 222-34.

Bayliss, A., D. Benson, D. Galer, L. Humphrey, L. McFadyen and A. Whittle, 2007: One thing after another. The date of the Ascott-under-Wychwood long barrow, Cambridge archaeological journal 17(S1), 29-44.

Bayliss, A., A. Whittle and M. Wysocki, 2007: Talking about my generation. The date of the West Kennet long barrow, Cambridge archaeological journal 17, 85-101.

Benson, D., 2006: The excavations of 1965-69, in D. Benson and A. Whittle (eds), Building memories. The Neolithic CotswoldSevern long barrow at Ascott-under-Wychwood, Oxfordshire, Oxford, 122.

Bickle, P., 2020: Thinking gender differently. New approaches to identity difference in the Central European Neolithic, Cambridge archaeological journal, 30(2), 201-18.

Bloch, M., 1971: Placing the dead. Tombs, ancestral villages and kinship organization in Madagascar, New York.

Booth, T.J., 2019: A stranger in a strange land. A perspective on archaeological responses to the palaeogenetic revolution from an archaeologist working amongst palaeogeneticists, World archaeology 51(4), 586-601.

Borić, D., 2008: First households and 'house societies' in European prehistory, in A. Jones (ed.), Prehistoric Europe. Theory and practice, Oxford, 109-42.

Brace, S., Y. Diekmann, T.J. Booth et al., 2019: Ancient genomes indicate population replacement in Early Neolithic Britain, Nature ecology and evolution 3, 765-77.

Brück, J., 2021: Ancient DNA, kinship and relational identities in Bronze Age Britain, Antiquity 95, 228-37.

Carsten, J., 2004: After kinship, Cambridge.

Carsten, J., and S. Hugh-Jones (eds), 1995: About the house. Lévi-Strauss and beyond, Cambridge.

Cassidy, L.M., R. Ó Maoldúin, T. Kador et al., 2020: A dynastic elite in monumental Neolithic society, Nature 582, 384-88.

Cooney, G., 2016: Pathways to ancestral worlds. Mortuary practice in the Irish Neolithic, in K. Brophy, G. MacGregor and I. Ralston (eds), The Neolithic of mainland Scotland, Edinburgh, 74-94.

Corcoran, J.X.W.P., 1969: The Cotswold-Severn group. Distribution, morphology and artefacts, in T.G.E. Powell et al., Megalithic enquiries in the West of Britain, Liverpool, 13-71. 
Couderc, P., 2018: Houses for bones. Collective disposal of the dead among the Uut Danum of Borneo, in A. Schmitt, S. Déderix and I. Crevecoeur (eds), Gathered in death. Archaeological and ethnological perspectives on collective burial and social organisation, Louvain, 63-84.

Creese, J., 2012: The domestication of personhood. A view from the Northern Iroquoian longhouse, Cambridge archaeological journal 22, 365-86.

Cummings, V., 2002: Experiencing texture and transformation in the British Neolithic, Oxford journal of archaeology 21(3), 249-61.

Cummings, V., A. Jones and A. Watson, 2002: Divided places. Phenomenology and asymmetry in the monuments of the Black Mountains, southeast Wales, Cambridge archaeological journal 12, 57-70.

Cummings, V., and Richards, C., 2021. Monuments in the making. Raising the great dolmens in Early Neolithic Northern Europe, Oxford.

Cummings, V., and G. Robinson, 2015: The life and times of a chambered tomb. The results of survey and excavation at Blasthill chambered tomb, Kintyre, western Scotland, Archaeological journal 172(1), 1-29.

De Valera, R., 1960: The court cairns of Ireland, Proceedings of the Royal Irish Academy C, 60, 9-85.

Dowd, M., L. Lynch, L. Cassidy et al., 2020: Neolithic engagements with the dead. Mortuary processing on Bengorm Mountain in the north-west of Ireland, Oxford journal of archaeology 39(4), 368-94.

Ensor, B.E., 2021: Making aDNA useful for kinship analysis, Antiquity 95, 241-43.

Ensor, B.E., J.D. Irish and W.F. Keegan, 2017: The bioarchaeology of kinship. Proposed revisions to assumptions guiding interpretation, Current anthropology 58, 739-61.

Fleming, A., 1972: Vision and design. Approaches to ceremonial monument typology, Man 7(1), 57-73.

Fowler, C., 2001: Personhood and social relations in the British Neolithic, with a study from the Isle of Man, Journal of material culture 6(2), 137-63.

Fowler, C., 2002: Body parts. Personhood and materiality in the Manx Neolithic, in Y. Hamilakis, M. Pluciennik and S. Tarlow (eds), Thinking through the body. Archaeologies of corporeality, New York, 47-69.

Fowler, C., 2003: Rates of (ex)change. Decay and growth, memory and the transformation of the dead in early Neolithic southern Britain, in H. Williams (ed.), Archaeologies of remembrance. Death and memory in past societies, New York, $45-63$.

Fowler, C., 2004: In touch with the past? Bodies, monuments and the sacred in the Manx Neolithic, in V. Cummings and C. Fowler (eds), The Neolithic of the Irish sea. Materiality and traditions of practice, Oxford, 91-102.

Fowler, C., 2010: Pattern and diversity in the Early Neolithic mortuary practices of Britain and Ireland. Contextualising the transformation of the dead, Documenta praehistorica 37, 1-18.

Fowler, C., 2016: Relational personhood revisited, Cambridge archaeological journal 26(3), 397-412

Fowler, C., 2021a: Ontology in Neolithic Britain and Ireland. Beyond animism, Religions 12(4), 249, at https://doi.org/10. 3390/rel12040249.

Fowler, C., 2021b: Petrification in the Neolithic? Comparing the use of wood and stone in the architecture of Neolithic Britain and Ireland, in A. Gramsch, S. Hueglin and L. Seppanen (eds), Turning to stone. Petrification processes in (pre-)historic Europe, New York, 81-97.

Fowler, C., and Cummings, V., 2003: Places of transformation. Building monuments from water and stone in the Neolithic of the Irish Sea, Journal of the Royal Anthropological Institute 9(1), 1-20.

Fowler, C., and Olalde, I., V. Cummings, I. Armit, L. Büster, G.S. Cuthbert, H. Rohland, O. Cheronet, R. Pinhasi and D. Reich, 2021. A high-resolution picture of kinship practices in an Early Neolithic tomb, Nature.

Fried, M.H., 1975: The notion of the tribe, Menlo Park, CA.

Galer, D., 2006: The human remains, in D. Benson and A. Whittle (eds), Building memories. the Neolithic Cotswold long barrow at Ascott-under-Wychwood, Oxfordshire, Oxford, 189-220.

Gillespie, S., 2000a: Beyond kinship. An introduction, in R.A. Joyce and S.D. Gillespie (eds), Beyond kinship. Social and material reproduction in house societies, Philadelphia, 1-21.

Gillespie, S., 2000b: Lévi-Strauss. Maison and sociétié à maisons, in R.A. Joyce and S.D. Gillespie (eds), Beyond kinship. Social and materialreproduction in house societies, Philadelphia, 22-52.

González-Ruibal, A., 2006: House societies vs. kinship-based societies. An archaeological case from Iron Age Europe, Journal of anthropological archaeology 25, 144-73.

Jeunesse, C., and A. Denaire, 2018: Current collective graves in the Austronesian world. A few remarks about Sumba and Sulawesi (Indonesia), in A. Schmitt, S. Déderix and I. Crevecoeur (eds), Gathered in death. Archaeological and ethnological perspectives on collective burial and social organisation, Louvain, 85-106.

Johnston, R., 2020: Bronze Age worlds. A social prehistory of Britain and Ireland, London.

Jones, A., 1999: Local colour. Megalithic architecture and colour symbolism in Neolithic Britain, Oxford journal of archaeology 18(4), 339-50.

Jones, C., 2019: The north Munster atypical court tombs of western Ireland. Social dynamics, regional trajectories and responses to distant events over the course of the Neolithic, in J. Müller, M. Hinz and M. Wunderlich (eds), Megaliths, societies, landscapes. Early monumentality and social differentiation in Neolithic Europe, Bonn, 983-1004. 
Joyce, R.A. and S.D. Gillespie (eds), 2000: Beyond kinship. Social and material reproduction in house societies, Philadelphia. Kenney, J., 2020: A dialogue with the dead? The relationship between an Early Neolithic rectangular building and a chambered tomb on Holy Island, Anglesey, North Wales, in A. Barclay, D. Field and J. Leary (eds), Houses of the dead?, Oxford, 135-44.

Leary, J., D. Field and A. Barclay, 2020: Schrödinger's cat. Houses for the living and the dead, in A. Barclay, D. Field and J. Leary (eds), Houses of the dead?, Oxford, 1-14.

Lévi-Strauss, C., 1982: The way of the masks, Vancouver.

Lynch, F., and P. Davey (eds), 2017: The chambered tombs of the Isle of Man. A study by Audrey Henshall, 1969-78, Oxford. Mason, J., 2008: Tangible affinities and the real-life fascination of kinship, Sociology 42(1), 29-45.

McFadyen, L., 2006: Building technologies, quick and slow architectures and early Neolithic long barrow sites in southern Britain, Archaeological review from Cambridge 21(1), 117-34.

McFadyen, L., D. Benson and A. Whittle, 2007: The long barrow, in D. Benson and A. Whittle (eds), Building memories. The Neolithic Cotswold-Severn long barrow at Ascott-under-Wychwood, Oxfordshire, Oxford, 79-136.

Meadows, J., A. Barclay and A. Bayliss, 2007: A short passage of time. The dating of the Hazleton North long cairn revisited, Cambridge archaeological journal 17(S1), 45-64.

Neil, S., J. Evans, J. Montgomery and C. Scarre, 2016: Isotopic evidence for residential mobility of farming communities during the transition to agriculture in Britain, Royal Society Open Science 3, 150522.

Neil, S., J. Evans, J. Montgomery and C. Scarre, 2020: Isotopic evidence for human movement into central England during the Early Neolithic, European journal of archaeology 23(4), 512-29.

Neil, S., J. Montgomery, J. Evans, G. Cook and C. Scarre, 2017: Land use and mobility during the Neolithic in Wales explored using isotope analysis of tooth enamel, American journal of physical anthropology 164(2), 371-93.

Noble, G., 2006: Neolithic Scotland. Timber, stone, earth and fire, Edinburgh.

Noble, G., 2017: Woodland in the Neolithic of Northern Europe. The forest as ancestor, Cambridge.

Olalde, I., S. Brace, M. Allentoft et al., 2018: The Beaker phenomenon and the genomic transformation of northwest Europe, Nature 555, 190-96.

Parker Pearson, M., and D. Regnier, 2018: Collective and single burial in Madagascar, in A. Schmitt, S. Déderix and I. Crevecoeur (eds), Gathered in death. Archaeological and ethnological perspectives on collective burial and social organisation, Louvain, 41-62.

Parkin, R., 1997: Kinship. An introduction to the basic concepts, Oxford.

Pollard, J., 2006: A community of beings. Animals and people in the Neolithic of southern Britain, in D. Serjeantson and D. Field (eds), Animals in the Neolithic of Britain and Europe, Oxford, 135-48.

Powell, A., 2005: The language of lineage. Reading Irish court tomb design, European journal of archaeology 8(1), 9-28.

Ray, K., and J. Thomas, 2003: In the kinship of cows. The social centrality of cattle in the earlier Neolithic of southern Britain, in M. Parker Pearson (ed.), Food, culture and identity in the Neolithic and Early Bronze Age, Oxford, 45-51.

Ray, K., and J. Thomas, 2018: Neolithic Britain. The transformation of social worlds, Oxford.

Richards, C., (ed) 2005: Dwelling among the monuments. The Neolithic village of Barnhouse, Maeshowe passage grave and surrounding monumentsat Stenness, Orkney, Cambridge.

Richards, C., and R. Jones, (eds) 2016: The development of Neolithic house societies in Orkney, Oxford.

Sahlins, M., 1961: The segmentary lineage. An organization of predatory expansion, American anthropologist 63, 322-43.

Sánchez-Quinto, F., F. Malmström, M. Fraser et al., 2019: Megalithic tombs in western and northern Neolithic Europe were linked to a kindred society, Proceedings of the National Academy of Sciences 116(19), 9469-74.

Scheib, C.L., R. Hui, E. D’Atanasio et al., 2019: East Anglian early Neolithic monument burial linked to contemporary megaliths, Annals of human biology 46(2), 145-49.

Schmidt, A., S. Déderix and I. Crevecoeur (eds), 2018: Gathered in death. Archaeological and ethnological perspectives on collective burial and social organisation, Louvain.

Schmidt, A., and S. Déderix, 2018: What defines a collective grave? Archaeological and ethnological perspectives on collective burial practices, in A. Schmitt, S. Déderix and I. Crevecoeur (eds), Gathered in death. Archaeological and ethnological perspectives on collective burial and social organisation, Louvain, 195-214.

Schneider, D., 1984: Critique of the study of kinship, Ann Arbor.

Schulting, R., and M. Wysocki, 2005: 'In this chambered tumulus were found cleft skulls ...'. An assessment of the evidence for cranial trauma in the British Neolithic, Proceedings of the Prehistoric Society 71, 107-38.

Sheridan, A., and R. Schulting, 2020: Making sense of Scottish Neolithic funerary monuments. Tracing trajectories and understanding their rationale, in A.B. Gebauer, L. Srensen, A. Teather and A. Carlos Valera (eds), Monumentalising life in the Neolithic. Narratives of change and continuity, Oxford, 195-216.

Smith, M., and M. Brickley, 2009: People of the long barrows. Life, death and burial in the Earlier Neolithic, Stroud.

Smyth, J., 2014: Settlement in the Irish Neolithic. New discoveries on the edge of Europe, Oxford.

Smyth, J., 2020: House of the living, house of the dead. An open and shut case from Ballyglass, Co. Mayo?, in A. Barclay, D. Field and J. Leary (eds), Houses of the dead?, Oxford, 145-58.

Stone, L., and D. King, 2019: Kinship and gender. An introduction, 6th edn, London. 
Thomas, J., 1988: The social significance of Cotswold-Severn burial rites, Man 23, 540-59.

Thomas, J., 1999: Understanding the Neolithic, London.

Thomas, J., 2000: Death, identity and the body in Neolithic Britain, Journal of the Royal Anthropological Institute 6, 603-17.

Thomas, J., 2002: Archaeology's humanism and the materiality of the body, in Y. Hamilakis, M. Pluciennik and S. Tarlow (eds), Thinking through the body. Archaeologies of corporeality, New York, 29-46.

Thomas, J., 2013: The birth of Neolithic Britain. An interpretive account, Oxford.

Thomas, J., 2015: House societies and founding ancestors in Early Neolithic Britain, in C. Renfrew, M. Boyd and I. Morley (eds), Death rituals, social order and the archaeology of immortality in the ancient world, Cambridge, 138-52.

Waterson, R., 1995: Houses and hierarchies in island southeast Asia, in J. Carsten and S. Hugh-Jones (eds), About the house. Lévi-Strauss and beyond, Cambridge, 47-68.

Waterson, R., 2013: Transformations in the art of dwelling. Some anthropological reflections on Neolithic houses, in D. Hofmann and J. Smyth (eds), Tracking the house in Neolithic Europe. Sedentism, architecture, and practice, New York, 373-96.

Whittle, A., 2003: The archaeology of people. Dimensions of Neolithic life, London.

Whittle, A., A. Barclay, A. Bayliss, L. McFadyen, R. Schulting and M. Wysocki, 2007a: Building for the dead. Events, processes and changing worldviews from the thirty-eighth to the thirty-fourth centuries cal. BC in southern Britain, Cambridge archaeological journal 17(S1), 123-47.

Whittle, A., A. Barclay, L. McFadyen, D. Benson and D. Galer, 2007b: Place and time. Building and remembrance, in D. Benson and A. Whittle (eds), Building memories. The Neolithic Cotswold long barrow at Ascott-under-Wychwood, Oxfordshire, Oxford, 327-64.

Whittle, A., A. Bayliss and M. Wysocki, 2007: Once in a lifetime. The date of the Wayland's Smithy long barrow, Cambridge archaeological journal 17(S1), 103-21.

Whittle, A., and P. Bickle, 2013: Performing LBK lifeways, in P. Bickle and A. Whittle (eds), The first farmers of central Europe. Diversity in LBK lifeways, Oxford, 387-403.

Wysocki, M., A. Bayliss and A. Whittle, 2007: Serious mortality. The date of the Fussell's Lodge Long Barrow, Cambridge archaeological journal 17(S1), 65-84.

Wysocki, M., and A. Whittle, 2000: Diversity, lifestyles and rites. New biological and archaeological evidence from British Earlier Neolithic mortuary assemblages, Antiquity 74, 591-601.

Chris Fowler is a Senior Lecturer in Prehistoric Archaeology at Newcastle University. His research interests include personhood, bodies and life courses, mortuary practices, the application of relational theoretical approaches in archaeology, and Neolithic and Early Bronze Age Britain and Ireland.

Cite this article: Fowler C (2022). Social arrangements. Kinship, descent and affinity in the mortuary architecture of Early Neolithic Britain and Ireland. Archaeological Dialogues 29, 67-88. https://doi.org/10.1017/S1380203821000210 